Jurnal Professional FIS UNIVED Vol. 2 No.2 Desember 2015

\title{
PEMBINAAN ORANG TUA DALAM MENGHADAPI PERILAKU ANAK YANG MENYIMPANG (STUDI DI DESA BUNGA TANJUNG MUKOMUKO BENGKULU)
}

\section{Oleh:}

\author{
YANTO \\ Dosen Prodi Ilmu Komunikasi Fakultas Ilmu-Ilmu Sosial UNIVED Bengkulu
}

\begin{abstract}
The background ofthis studywas the high number of children in primary school age diddeviant behavior, especially in Bunga Tanjung village, Mukomuko, Bengkulu. This phenomenon occured because of the bandwagon attitude were present in children which they adopted from their surrounding environment. Unfortunately adults didn't realize that their attitudes and behavior which imitated by children could be fatal to the development of their behavior later in life. Ironically, most parents, educators, and community leaders had not paid serious attention to this issue. Based on the above phenomen on writer interested in studying further the issues of children's deviant behavior and ways taken by parents to deal with children with deviant behaviorin the review of Transactional and Behavioral Analysis. This is afield research which apllied qualitative descriptive analysis method to accurately explain the phenomen on that was found inthe field which critically analyzed and described innarrative from 34 informants who were taken by using snowball sampling technique. The results showed in terms of Transactional, parents used ago state, complementary dan stimulus hunger and strokes. In terms of Behavioral Analysis, parents used operan conditional, imitative learning, giving reward and punishment, reinforsing incompatible behaviours, and operan habituation.
\end{abstract}

\section{Keywords: Edification, Parents Deviant Behavior}

\section{PENDAHULUAN}

Manusia adalah ciptaan Tuhan yang paling indah dan istimewa. Tiada satupun ciptaan Tuhan yang menyamai keberadaan manusia. Manusia merupakan sumber energi yang apabila dikembangkan dengan benar, akan mampu mendatangkan kebahagiaan dan kesenangan, baik itu untuk dirinya sendiri maupun bagi makhluk lainnya.

Dalam hal ini Peran keluarga juga sangat dibutuhkan, keluarga merupakan ikatan kelompok sosial yang terkecil (Sayekti, 1994:10). Keluarga juga merupakan tempat yang pertama bagi anak untuk mengenal hidup. Apapun yang terjadi dalam keluarga baik perasaan, perilaku dan pergaulan orang tua di rumah ataupun di luar rumah akan mempengaruhi perkembangan anak. Oleh sebab itu, orang tua harus menjadi pendidik, teman dan suri tauladan bagi anak, karena orang tualah yang akan membentuk kepribadian anak. Seperti yang dijelaskan dalam hadits Rasulullah berikut ini:

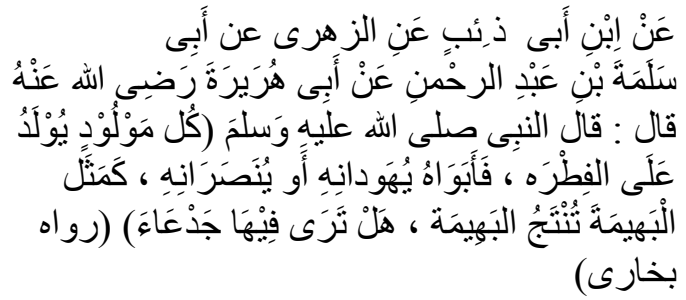

Artinya: "Dari Ibn Abi Dzi’bin bercerita kepada kami dari al-Zuhri dari Abu Salamah ibn Abd al-Rahman dari 
Abu Hurairah r.a ia berkata: Nabi SAW bersabda: Setiap anak yang dilahirkan adalah dalam keadaan fitrah. Maka kedua orang tuanyalah yang menjadikannya Yahudi, Nasrani, atau Majusi. Sebagaimana binatang ternak yang telah melahirkan anak-anaknya, apakah engkau ada melihat sumbing (cacat) telinganya?" (HR.al-Bukhari). (Abi Abdillah Muhammad bin Ismail AlBukhari $1400 \mathrm{H}$ : 424)

Perubahan zaman saat ini telah membawa banyak perubahan pada segenap tatanan kehidupan masyarakat yang berakibat pada renggangnya interaksi dalam keluarga. Ayah terlalu sibuk dengan pekerjaannya sehingga kurang perhatian terhadap istri dan anakanaknya. Ibu pun harus ikut-ikutan bekerja untuk memperoleh uang, karena tuntutan ekonomi. Pada masyarakat modern yang serba kompleks sekarang ini tidak ada seorang pun yang terbebas dari masalah-masalah kehidupan. Kemajuan teknologi, mekanisasi, industrialisasi dan urbanisasi, membuat sulitnya individu melakukan adaptasi terhadap perubahan-perubahan sosial.

Untuk itu seseorang harus belajar menanggapi berbagai konflik dan kesulitan hidupnya. Sehingga tidak menimbulkan dampak negatif terhadap perkembangan anak-anaknya seperti prilakunya yang menyimpang, kenakalan, kejahatan, menghisap ganja dan kecanduan narkotika dan lain sebagainya.

Ketika sang Anak berada pada tahap akhir masa kanak-kanak dan memasuki masa puber atau pra masa remaja, usia yang penuh gejolak. Apabila kita lihat realita yang ada pada saat ini yang sangat mengkhawatirkan bagi generasi sekarang ini. Seluruh mode dan trend masa kini dapat diakses melalui televisi, dan sebagainya. Namun, pengetahuan yang sedemikian banyak itu dapat membuat kekacauan dan berbahaya seperti Kurikulum sekolah telah disesuaikan untuk mengajarkan topik-topik baru, AIDS, penyalahgunaan obat-obatan dan alkohol, fragmen kekerasan dan seks terpampang di televisi dan menetap dalam benak mereka. Pesan-pesannya sangat kuat dan kontradiktif apalagi bagi mereka yang berada pada tahap pra puberitas atau akhir masa anak-anak. Klip musik rock menayangkan pesta seks bebas. Pejabat kesehatan masyarakat menyarankan seks yang aman, yang seharusnya belum konsumsi mereka. Bahaya dunia orang dewasa kadang-kadang godaannya sangat fatal jika sangat awal diterima oleh anak-anak sehingga idealisme mereka bisa luntur.

Tak dapat dipungkiri lagi bahwa akhir masa anak-anak atau masa pra pubertas adalah masa yang labil, penuh tantangan dan godaan. Anak memasuki tahap baru dalam kehidupan, seperti halnya penyesuaian diri dengan harapan sosial yang baru. Sebagian anak menganggap periode metamorfosis ini merupakan periode yang sulit dalam kehidupan mereka. Pada tahap ini terjadi tumpang tindih di mana seorang anak tidak bisa lagi dianggap sebagai anakanak tetapi belum juga bisa dianggap sebagai remaja (Hurlock, 1980: 185).

Kebanyakan orang tua berpendapat bahwa akhir masa kanak-kanak merupakan usia yang menyulitkan, karena pada masa ini anak tidak mau lagi menuruti perintah orang tua. Anak-anak lebih banyak dipengaruhi oleh temanteman sebayanya dari pada oleh orang tua dan keluarga. Pada masa ini juga disebut dengan usia tidak rapi, suatu masa dimana anak cendrung tidak mempedulikan dan ceroboh dalam penampilan dan berantakan.Sementara para pendidik melabelkan akhir masa kanak-kanak dengan usia sekolah dasar dan periode kritis dalam dorongan berprestasi, yaitu suatu masa dimana 
anak membentuk kebiasaan untuk mencapai sukses, tidak sukses atau sangat sukses yang cendrung menetap sampai dewasa. Para ahli psikologi melabelkan akhir masa kanak-kanak adalah usia berkelompok, suatu masa dimana perhatian utama anak tertuju pada keinginan diterima oleh temanteman sebayanya sebagai anggota kelompok (Hurlock, 1980: 146-147).

Selanjutnya Piaget juga mengatakan bahwa antara usia lima sampai dua belas tahun, konsep moral anak tidak lagi sesempit dan sekhusus sebelumnya, konsep anak mengenai keadilan sudah berubah. Pengertian yang kaku dan keras tentang benar dan salah yang dipelajari dari orang tua, menjadi berubah dan anak mulai memperhitungkan keadaan-keadaan khusus di sekitar pelanggaran moral. Jadi relativisme moral menggantikan moral yang kaku. Misalnya bagi anak lima tahun, berbohong itu selalu buruk, sedangkan anak yang lebih besar sadar bahwa dalam beberapa situasi, berbohong dibenarkan sehingga mereka menyimpulkan berbohong tidak selalu buruk (Hurlock, 1980: 163).

Peran orang tua sangat dibutuhkan dalam mengontrol perilaku anak yang berada pada usia akhir masa kanak-kanak. Sebab pada masa ini perhatian anak lebih tertuju pada teman sebaya dibandingkan pada keluarga. Pada masa ini anak juga memasuki usia prapubertas yang penuh dengan gejolak. Jika orang tua tidak memberikan perhatian, kasih sayang, kemungkinan anak akan menjadi bingung, risau, malu, sering diliputi perasaan dendam dan benci sehingga anak menjadi kacau dan liar. Sehingga di kemudian hari mereka mencari kompensasi bagi kerisauan batin sendiri di luar lingkungan keluarga yaitu menjadi anggota dari suatu gang kriminal, lalu melakukan banyak perbuatan brandalan dan criminal, melihat dari fenomena yang begitu nyata telah merusaki perilaku anak-anak maka sebagai orang tua

Kehidupan generasi muda saat ini sudah tidak asing lagi dengan berbagai macam kenakalan, yang juga ditiru dan diikuti oleh anak-anak. Mulai dari kebutkebutan di jalan raya, perilaku ugalugalan, perkelahian antar gang, membolos sekolah lalu berkeliaran di sepanjang jalan, mencopet, berpesta pora sambil mabuk-mabukkan, perkosaan, kecanduan dan ketagihan bahan narkotika, melakukan tindakan amoral secara terang-terangan, perjudian, komersialisasi dan lain sebagainya. Sangat ironis memang, ketika masyarakat dunia berusaha untuk meningkatkan kesejahteraannya, kenakalan remaja dan anak-anak pun semakin meningkat.

Tindakan kriminal yang mereka lakukan bukan hanya merupakan perbuatan yang melawan hukum semata, dan melanggar norma masyarakat. Perbuatan-perbuatan tersebut menimbulkan gangguan-gangguan terhadap keamanan, ketentraman dan ketertiban masyarakat.

Berdasarkan fenomena di atas, maka penulis tertarik untuk membahas permasalahan ini. Apalagi ini terjadi di daerah yang masih mempunyai kultural yang masih alami, Apalagi ketika perilaku menyimpang itu tersebar luas dan mengimbas pada dunia anak-anak yang seharusnya tugas mereka adalah belajar. Tentu saja hal itu akan mempengaruhi masa depan mereka yang masih panjang, jika tidak didapatkan penanganan yang tepat terhadap kenakalan mereka.Untuk lebih terarahnya penelitian ini, maka penelitian ini dibatasi pada:Bagaimana pembinaan orang tua dalam menghadapi perilaku menyimpang anak di tinjau dari Analisis Transaksional di Desa Bunga Tanjung dan Bagaimana pembinaan 
orang tua dalam menhadapi perilaku menyimpang anak di tinjau dari analisis Behavioral di desa Bunga Tanjung.

\section{METODE PENELITIAN}

Penelitian ini merupakan penelitian lapangan (field research) yaitu penulis turun langsung ke lapangan untuk mengambil data. Penelitian ini menggunakan pendekatan deskriptif kualitatif yaitu menjelaskan fenomena secara akurat yang di temukan di lapangan yang selanjutnya dianalisa secara kritis dan di deskripsikan secara naratif. (Moleong, 2001: 3).

Dengan menggunakan Metode deskriptif dapat diartikan sebagai prosedur pemecahan masalah yang diselidiki dengan menggambarkan atau melukiskan keadaan objek penelitian pada saat sekarang berdasarkan faktafakta sebagaimana adanya di lapangan. (Nabawi dan Martini,1996:73)

\section{Subjek Penelitian}

Subjek penilitian dari penilitian ini adalah anak usia sekolah dasar yang berada di desa Bunga Tanjung, kecamatan Teramang Jaya, kabupaten Mukomuko, Provinsi Bengkulu, yang berjumlah 110 orang, penelitian di ambil secara snowball sampling yaitu sampel di ambil berdasarkan data dan informasi yang penulis butuhkan, lebih lanjut Burhan Bungin (2003: 53) menjelaskan ada tiga tahap dalam pengambilan sampel yaitu pemilihan sampel awal, pemilihan sampel lanjutan dan menghentikan pemilihan bila dianggap sudah variasi dan informasi, maka dalam penelitian ini ditetapkan subjek penelitian sebanyak 34 orang, 19 orang tua, 10 anak, dan tokoh masyarakat 5 orang.

2. Alat Pengumpulan data

Data-data penelitian ini di kumpulkan dengan cara:

Observasi adalah alat
pengumpul data yang dilakukan dengan cara mengamati dan mencatat secara sistematis gejalagejala yang di selidiki (Narbuko dan Ahmadi, 2005: 70). Penelitian ini dilakukan oleh penulis dengan cara terjun langsung ke lapangan dengan melihat, dan mengamati fenomena yang ada di Desa Bunga Tanjung, Muko-Muko, Bengkulu mengenai Pembinaan Orang Tua Dalam Menghadapi Perilaku Anak Yang Menyimpangdi Tinjau Dari Model Konseling.

b. Wawancara (interview)

Merupakan pertemuan dua orang untuk bertukar informasi dan ide melalui tanya jawab, sehingga dapat dikonstruksikan makna dalam suatu data tertentu. (Beni Ahmad Saebani, 2008) dimana pada penelitian ini peneliti berdialog langsung dengan subjek penelitian, dalam hal ini anak-anak orang tua dan tokoh masyarakat.

c. Studi Dokumentasi

Studi dokumentasi adalah mencari data mengenai hal-hal yang berupa catatan, transkrip, buku, notulen, agenda, foto dan sebagainya. Dalam hal ini yang diamati bukan benda hidup tetapi benda mati (Arikunto,2002:206). Yang dimaksud dalam hal ini adalah dokumentasi yang dapat di peroleh dan yang berkenaan dengan masalah yang penulis teliti.

3. Teknik Pengolahan Data

Analisa data dalam penelitian ini sudah mulai sejak memperoleh data awal di lapangan dan bisa di lakukan perulangan sesuai dengan temuan berikutnya. Data yang diolah secara kualitatif dan disajikan dalam bentuk narasi (Narbuko, dkk. 2000:14).

Data yang diperoleh berupa data mentah yang diolah untuk menjawab pertanyaan penelitian. Maka prosedur yang perlu dilakukan adalah: 
a. Memeriksa data yaitu: Memeriksa data yang terkumpul melalui observasi, wawancara serta dokumentasi dengan menyesuaikan sesuai dengan masalah penelitian.

b. Klasifikasi dan analisis data: yaitu mengklasifikasikan atau mengelompokkan data yang terkumpul sesuai dengan masalah penelitian. Setelah itu data yang dikelompokkan sesuai batasan dan rumusan, maka penulis melakukan penganalisaan data.

c. Visualisasi data yaitu data yang telah terkumpul dengan rapi dapat ditampilkan dengan jelas melalui paparan kata yang berbentuk narasi untuk menggambarkan semua data yang sesuai dengan penelitian.

\section{HASIL PENELITIAN Pembinaan Orang Tua Di Tinjau Dari Analisis Transaksional}

Pada bab ini penulis membahas tentang pembinaan orang tua ditinjau dari transaksional. Model ini dipelopori oleh Erick Berne semenjak 1950, transaksional maksudnya adalah hubungan komunikasi dengan orang lain (Taufik, 2002: 95).

Model ini memendang bahwa setiap individu itu merupakan satu kesatuan dari tiga ego state yaitu:

1. Ego state parent, yang lebih di warni pada perintah sanksi, yang cendrung statis.

2. Ego state adult, berorientasi pada fakta, realistis dan dinamis.

3. Ego state child, spontan, kreatif, penuh gaya dan cendrung bermanjaan. (Prayitno, 1998: 54).

Penyebab timbulnya perilaku menyimpang adalah karena kurangnya perhatian dari orang tua, ini menunjukkan bahwa terjadi hubungan komunikasi yang kurang baik antara anak dan orang tua, sehingga anak akan melakukan apa yang menurut mereka benar saja.

Banyak anak yang memelatarbelakangi melakukan perilaku menyimpang ini terlihat bahwa anak lebih banyak menonjolkan adul statet yang lebih menonjolkan sifat realistisnya ketika terjadi komunikasi cross (menyilang) dengan teman sebayanya yang menurutnya tidak baik, sehingga membuat Ia tersinggung maka ketika itu emosinya mudah naik sehingga terjadilah perkelahian dan sebagainya.

Dalam model analisis transaksional yang mengatakan bahwa individu mempunyai kebutuhan untuk meroleh sentuhan (stimulus hanger and strokes), yang mana diberi semacam tindakan yang tidak biasa ia dapatkan, sehingga anak akan merasa asing dengan tingkah yang ditunjukan dan menyadari akan kesalahan lalu merubah tingkah laku yang salah.

Dapat dipahami bahwa terjadi life position yang tidak baik dengan orang tua yang mana orang tua selalu menganggap dirinya lah yang lebih baik, sehingga terjadi lah "saya tidak oke", hal ini bisa dilihat bahwa perintah orang tua tidak dilaksanakannya, di sini juga akan terjadi (injuction) peningkatan emosi yang ada dalam diri orang tua, sehingga mengambil tindakan tidak mau ambil pusing dengan anaknya.

Dari observasi dan wawancara penulis temukan di lapangan ternyata memang ketika menghadapi anak yang melakukan perilaku menyimpang memerlukan perhatian khusus, dan menempatkan anak pada posisinya sesuai dengan ago state yang di miliki oleh setiap individu, dan komunikasi yang baik atau sejajar (complementary) karena anak memerlukan perhatian dan sentuhan-sentuhan seperti itu untuk merubah dan menjegah terjadi nya perilaku menyimpang. 
Pembinaan Orang Tua ditinjau dari Analisis Behavioral

Pembahasan selanjutnya penulis akan memaparkan tentang pembinaaan orang tua terhadap anak yang melakukan perilaku menyimpang di tinjau dari analisis behavioral yang di kembangkan oleh Berne. Behavioristik menjelaskan tentang manusia yang bersifat falsafah dan psikologi antara lain:

1. Manusia pada dasarnya tidak berakhlak baik atau buruk, bagus atau jelek, manusia mempunyai potensi untuk bertingkah laku baik dan buruk, tepat atau salah, berdasarkan bakal keturunan dan pembawaan dan berkat interaksi antara bekal keturunan dan lingkungannyaakan menciptakan corak tingkah laku yang khas pada kepribadian.

2. Manusia mampu merefleksi atas tingkah lakunya sendiri, menangkap apa yang dilakukannya, dan mengatur serta mengontrol perilakunya sendiri.

3. Manusia mampu untuk memperoleh dan membentuk sendiri suatu pola tingkah laku yang baru melalui proses belajar, pola itu bisa juga diganti dengan usaha belajar yang baru.

4. Manusia dapat mempengaruhi perilaku orang lain dan dirinya dan dipengaruhi oleh orang lain(Winkel, 1997: 419).

Dari keyakinan mendasar tentang manusia diatas dapat di katakan bahwa perilaku merupakan hasil dari keseluruhan pengalaman hidupnya dalam berinteraksi dengan lingkungan. Kalau ditinjau perilaku itu dipandang tepat dan sesuai dengan situasi kehidupan nya, dan tidak tepat dan salah suai, Tepat atau tidaknya tingkah laku itu merupakan hasil dari proses belajar, dan itu juga bisa dihapus melalui proses belajar yang baik.
Dari penjelasan diatas jelas bahwa yang menjadi penyebab anak melakukan perilaku menyimpang adalah, dari luar seperti pengaruh teknologi yang berkembang begitu pesat dan timbulnya kemerosotan moral orang-orang di lingkungan, sehingga apa yang mereka lihat akan tertanam dalam diri mereka karena anak berada dalam masa pembelajaran, sehingga sangat mudah melakukan apa yang di lakukan oleh orang sekitar.

Pada teori behavioral yang mengatakan bahwa tingkah laku di pelajari ketika individu berinteraksi dengan lingkungan, melalui hukumhukum belajar, seperti memberikan kesibukan, dan pembiasaan yang bersifat positif untuk menghapus stimulus dan respon yang mereka dapat.

Anak tidak akan menyalahkan dirinya sendiri, melainkan faktor keluarga juga berpengaruh dalam penyimpangan perilaku yang dilakukan, terutama sang Ayah yang sering keluar malam, mabuk-mabukan, ketika anak tidak mendapat contoh yang baik dalam keluarga, karena diketahui bahwa begitu penting pemberian contoh (imitative learning), dan penguatan tentang apa yang di lakukan oleh anak (reinforcement), sehingga anak akan merasa dihargai.

Wawancara yang penulis lakukan di atas bisa di temuai di teori behavioral yang menggunakan teknik penghapusan respon yang telah di pelajari (yang membentuk pola tingkah laku) terhadap perangsang, dengan demikian responrespon yang baru akan dapat di bentuk.

Dari hasil observasi dan wawancara yang dilakukan oleh penulis kepada narasumber di lokasi penelitian yang terkait dengan pembinaan orang tua terhadap anak yang melakukan perilaku menyimpang di tinjau dari model konseling behavioral adalah: langsung mengambil tindakan apabila anak 
melakukan kesalahan, pemberian contoh yang baik terhadap anak (imitative learning), memberikan penguatan setiap perilaku yang di lakukan dengan memberikan hadiah (reward) danhukuman (punishment), penghapusan respon terhadap apa yang telah tertanam dalam diri anak dengan memberikan kesibukan, mengisi waktu luang yang anak miliki dengan melakukan hal-hal yang positif, dan memberikan bahaya yang akan di dapatkannya ketika mereka melakukan hal yang salah, memberikan didikan agama sejak dini.

\section{PENUTUP}

\section{Kesimpulan}

Berdasarkan hasil penilitian di atas maka penulis dapat menarik kesimpulan sebagai berikut.

1. Pembinaan orang tua dalam menghadapi perilaku anak yang menyimpang di tinjau dari analisis transaksional adalah: Dengan melakukan perhatian khusus, dan menempatkan anak pada posisinya sesuai dengan ago state yang di miliki oleh setiap individu, dan komunikasi yang baik atau sejajar (complementary) karena anak memerlukan perhatian dan sentuhansentuhan, dan Semuanya itu tentu memerlukan kerjasama yang baik dengan masyarakat komunikasi yang baik untuk menerapkan norma-norma yang berlaku untuk menjegah muncul dan berkembangnya perilaku menyimpang di kalangan anak.

2. Pembinaan orang tua dalam menghadapi perilaku anak yang menyimpang di tinjau dari analisis behavioural adalah: langsung mengambil tindakan apabila anak melakukan kesalahan (operan conditional) pemberian contoh yang baik terhadap anak (imitative learning), memberikan penguatan setiap perilaku yang di lakukan dengan memberikan hadiah (reward) danhukuman (punishment), penghapusan respon terhadap apa yang telah tertanam dalam diri anak dengan memberikan kesibukan, mengisi waktu luang yang anak miliki dengan melakukan hal-hal yang positif (pembiasaan operan), dan memberikan bahaya yang akan di dapatkannya ketika mereka melakukan hal yang salah, memberikan didikan agama sejak dini.

\section{Saran}

Mudah-mudahan saran ini dapat bermanfaat dalam perbaikan dan peningkatan menuju perilaku yang lebih baik bagi anak yang ada di desa Bunga Tanjung, untuk masa yang akan datang, karena dimensi-dimensi yang di miliki oleh manusia harus berjalan dengan sejajar, sehingga tidak menimbulkan masalah pada individu terutama pada anak-anak .

\section{DAFTAR PUSTAKA}

Ali, Mohammad dkk. (2004). "Psikologi Remaja (Perkembangan Peserta Didik)". Jakarta: PT Bumi Aksara.

Hurlock,Elizabeth.(1978)."Perkembanga n Anak Edisi Keenam”. Jakarta : Erlangga.

Perkembangan Edisi Kelima".
Jakarta: Erlangga.
Lexi, Moleong J.(2001). "Metode
Penelitian Kualitatif". Bandung:
PT. Remaja Rosdakarya.
Najati, Muhammad Utsman. (2004).
"Psikologi Dalam Perspektif
Hadits". Jakarta: Pustaka A1
Husna Baru.

Pujosuwarno, Sayekti.(1994).

"Bimbingan Dan Konseling 
Keluarga”. Yogyakarta: Menara Mas Offset.

Saebani, Beni Ahmad. (2008). "Metode Penelitian". Bandung: Pustaka Setia.

Sarwono, Sarlito Wirawan. (2006). "Psikologi Remaja". Jakarta: PT Raja Grafindo Persada.

Suharsismi, Arikunto. (2006). "Prosedur-Penelitian". Bandung: PT Remaja Rosdakarya.
Sunarto, \& Hartono Agus. (1995). "Perkembangan Peserta Didik". Jakarta: Rineka Cipta.

Suyanto, Bagong. (2005). "Metode Penelitian Sosial". Jakarta: Kencana Prenada Media Group.

Taufik. (2002).“Model-Model Konseling”.Padang: Universitas Negeri Padang.

Winkel, W.S. (1997).“Bimbingan Dan Konseling Di Institusi Pendidikan”. Jakarta: Grasindo. 